\title{
НЕНАД ЛУКИТ
}

\section{БЕОГРАДСКЕ РУЧНЕ ПИВАРЕ У ХІХ ВЕКУ}

\begin{abstract}
Сажетак: Развој Београда, утицај пиварских радника из Хабзбуршке монархије, почетак потрошње пива и уносност пиварског заната, пробудили су тридесетих година XIX века интересовање за отварање малих пиварских радионица у Београду. Вино и ракија, као традиционална пића, тада добијају конкуренцију у пиву, које ће с временом постајати све популарнији напитак међу Београђанима. У раду се на основу историјских извора и литературе прати развој и историја ручних пивара које су радиле у Београду током ХІХ века и које су биле претеча данашње модерне пиварске индустрије.
\end{abstract}

Кључне речи: Вајнхаплова пивара, Кнежева пивара, Мала пивара, Куманудијева пивара, Јохан Вајнхапл, Стеван Тодоровић, Игњат Вајферт, Филип Ђорђевић, Прво српско акционарско пиварско друштво, фамилија Бајлони

Abstract: In the 1830s, the growth of Belgrade, the influence of master brewers from the Habsburg Monarchy, the beginnings of beer consumption and the profits that could be gained from beer making aroused interest in starting small breweries in Belgrade. Traditional beverages, wine and brandy, were getting competition from beer, which became increasingly popular among Belgraders over time. Based on historical sources and literature, this paper traces the history of hand-operated breweries in Belgrade during the 19th century as forerunners of the modern beer industry.

Keywords: Weinhappl Brewery, Prince's Brewery, Small Brewery, Kumanudi Brewery, Johan Weinhappl, Stevan Todorović, Ignjat Vajfert (Weifert), Filip Djordjević, First Serbian Joint-Stock Brewery, Bajloni family

\section{Пиварство у Србији и Београду до XIX века}

H а основу врло оскудних и посредних историјских извора, данас је тешко дати прецизан одговор када су Срби почели да се баве производњом и конзумацијом пива. Стојан Новаковић, који се бавио овом темом, закључио је да је процес прављења пива код нас био познат још у средњем веку. Писмо краља Владислава (1234-1243) манастиру Бистрица у Полимљу, Светостефанска хрисовуља и Грачаничка повеља краља Милутина (1282-1321) из првих деценија XIV века и Дечанска повеља краља Стефана Дечанског (13221331), те термини који се у њима употребљавају, наводе на закључак да су били познати поступци добијања слада из жита, варење (кување) пива и охмељавање. Из писма манастиру Бистрици у Полимљу види се да се пиво варило за Божић, јер се у њему наређује манастирским житељима да слаg сийљу колико итреба Божићу и ga gају хмеља йо уборак. ${ }^{1}$ Слично је с терминима и у осталим поменутим повељама, из чега се закључује да се пиво трошило на двору, у манастирима и на приватним поседима. На основу овога може се претпоставити да је традиција прављења и конзумирања пива настављена и за време Деспотовине, односно у време владавине деспота Стефана Лазаревића и Ђурађа Бранковића у првој половини XV века. О производњи пива у периоду између 1459. и 1717. године нема конкретних података, али то не значи да га није било и да није произвођено. Након освајања Београда 1521. године, Османлије су извршиле катастарске пописе Београда и села из његове околине у којима се види значајно узгајање пшенице а мање јечма, што указује на могућност да су мештани из околних села наставили да производе пиво и након пада Деспотовине. Потребно је нагласити да је 
у ово време вино било главно пиће, да се производило у знатним количинама, превасходно на манастирским поседима, што се види и из поменутих сачуваних турских катастарских пописа. ${ }^{2}$

По завршетку аустро-турског рата 1716-1718. године, Београд и околина су одредбама Пожаревачког мира након нешто мање од 200 година турске владавине дошли под хабзбуршку управу. У планском насељавању Немаца у Београд и околину, дошли су и многи пиварски мајстори, који су отворили прве занатске радионице за производњу пива. У изворима из тог времена помињу се следећи пиварски мајстори који су држали ручне пиваре и пивнице у Београду: Јохан Лајбенегер, Игњат Лојтенбахер, Мартин Сејфрид, Антон Прест, Андрија Хајниш, Јохан Келер, Јозеф Лојтенбахер (који је вероватно био у роду са поменутим Игњатом), Антон и Адам Швелер. Своју пивару имала је и аустријска управа у Београду, она се звала Коморска и издавана је у закуп. Једни од најпознатијих тадашњих пиварских мајстора била су и браћа Абрахам и Јакоб Кепиш. ${ }^{3}$ Током периода аустријске управе, пиво се трошило међу насељеним Немцима, у аустријској војсци, али и на двору београдског митрополита. Када су Османлије поновно освојиле Београд 1739. године, пиварски мајстори одселили су се у Земун и Панчево, где су наставили да се баве својим занатом.

По запису Милана Ђ. Милићевића, пиво се у Београд вратило тек након 100 година. Увожено је из Земуна, а почело се точити 1834/1835. године у механи „Манојлова башта“, која се налазила на простору данашње пијаце Зелени венац. У ту башту раgи иееферича су се из конака коg Велике иркве извозиле у волујским колима јейрве кнеїна Љубииа и іосйђа Томанија Обреновић, супруга Јеврема Обреновића, брата кнеза Милоша. Остало је забележено да су гости ове кафане у којој се точило пиво говорили да иду на забаву код gубоке баре, као и да је кнез Милош Обреновић 1838. године наложио пресељење суда у зграду у чијем је приземљу била управо механа „Манојлова башта“. 5

Тадашња државна управа српске кнежевине била је заинтересована за развој домаће производње и потрошње пива, превасходно из економских разлога, због прихода од повластичарских закупнина и такси на точење пива. Државно правитељство је имало овлашћење да издаје дозволе за изградњу пивара, али се строго водило рачуна да се избегавају локације у виноградарским окрузима како потрошња пива не би штетила потрошњи вина и тиме угрозила развој и напредовање виноградарства у земљи. Такође, Правитељство је морало да оцењује техничко уређење пивара, стручност запослених манипуланата и квалитет производње. ${ }^{6}$ Један од првих захтева за подизање пиваре поднео је крајем
1839. године београдски трговац Јоца Ћ. Јовановић. Он је имао намеру да подигне пивару у Топчидеру, негде између две постојеће чесме, како би могао да се снабдева водом, главном сировином у пиварству. У поменутом захтеву он је између осталог тражио и да његова пивара добије концесију на 30 година. Данас се зна да он није изградио пивару у Топчидеру, а да ли је то учинио на неком другом месту - за сада није познато. ${ }^{7}$

\section{Сл. 1. Ручна йроизвоgња йива \\ (Историјска докуменйаџчја БИП)}

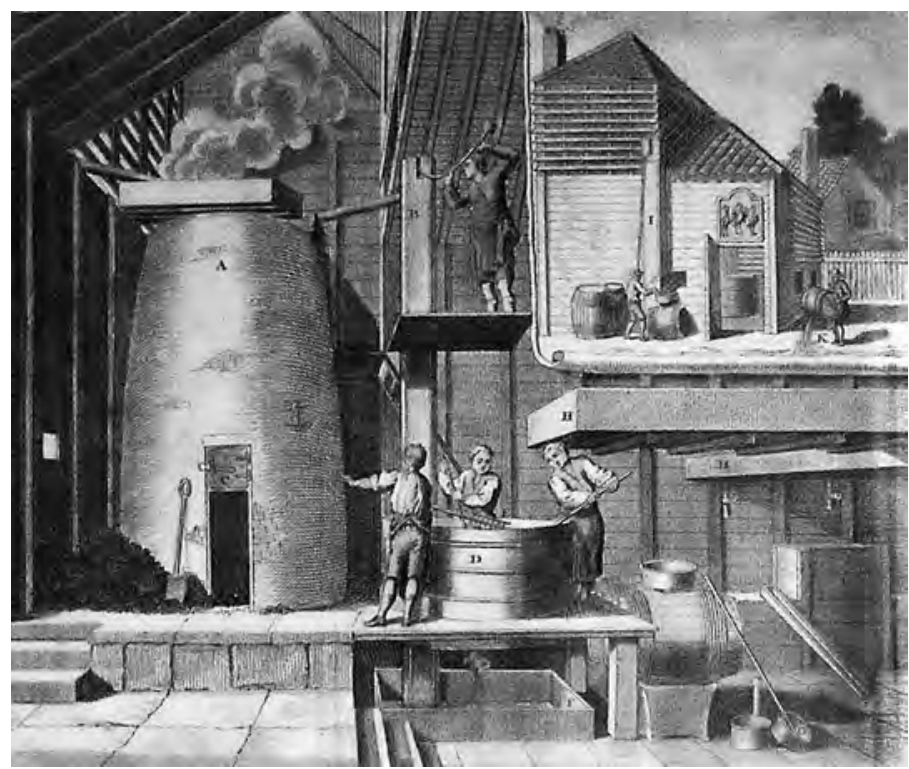

\section{Вајнхаплова пивара - прва београдска пивара (1839/1840-1848)}

Након договора са Алексом Симићем, изаслаником кнеза Милоша Обреновића, током децембра 1836. године у Земуну, Јохан Вајнхапл, угледни млинар из Сремске Митровице, одлучио је да дође у Србију и гради млинове и воденице. ${ }^{8}$ Крајем 1838, затражио је да буде примљен у српско поданство, те се овај његов захтев може довести у везу са жељом да се трајно настани у Србији како би наставио да се бави својим занатом, који је у то време био дефицитаран, али и са градњом прве радионице за варење пива у Београду. ${ }^{9}$ Иако се данас углавном користи и наводи 1839. година као она у којој је основана Вајнхаплова пивара, према расположивим изворима, производња и продаја пива највероватније су започеле наредне, 1840. године. На полеђини захтева за изградњу пиваре поменутог Јоце Ђ. Јовановића из децембра 1839, касније је накнадно дописано да је йрву йивару йоguі̃aо Вајнхайал и у иролеће 1840. іооине йочео gа вари иивво. ${ }^{10}$ Иако је реч о наводу који је на документу дописан касније, он је изгледа тачан, пошто у свом захтеву Јовановић на више 
места наводи да у то време у Београду не постоји ниједна пивара, што значи да нема ни Вајнхаплове. ${ }^{11}$ Забуну око тачне године када се почело производити пиво створио је један други документ, из 1841. године, који указује на то да је Вајнхаплова пивара основана 1839. године. Ради се о молби кнеза Михаила Обреновића Државном савету, у којој он тражи повластицу за новоизграђену Кнежеву пивару. У одговору Државног савета пише да је Вајнхаплова пивара почела радити две године раније, што би значило 1839. године, те се на основу овог документа поменута година углавном узима као она у којој је основана и с радом започела Вајнхаплова пивара. ${ }^{12}$ Очигледно је да проблем у ствари праве термини изграђена-основана, односно почела са радом, те се из тог разлога може претпоставити да је градњу пиваре Вајнхапл отпочео 1839, а производњу 1840. године. Данас нажалост није познато са сигурношћу ни где се тачно налазила прва београдска пивара у XIX веку. На основу Вајнхаплове молбе из 1847. године, у којој од Управе вароши Београда тражи зајам од 150 дуката цесарских за изградњу суваче-млина, може се само претпоставити да се пивара налазила на његовом имању на Врачару, отприлике тамо где се данас налази зграда Народне банке Србије, некада Народне банке Југославије. Вајнхапл у молби истиче да се последњих шест месеци због болести није могао бавити пиварским послом, што јасно указује да у наредном периоду није имао намеру да се бави само млинарством, пошто би новоизграђена сувача сигурно користила и његовој пивари за млевење слада, друге главне сировине у пиварству. ${ }^{13}$ Вајнхапл је убрзо умро, највероватније у првој половини 1848. године, не стигавши да у потпуности заврши сувачу. На поменутом плацу, који је био ширине 24 хвата, а дужине 25 хвати ${ }^{14}$, налазиле су се недограђена сувача, затим једна кућа, кујна, магаза и штала за шест коња. ${ }^{15}$ Као што се из пописа имовине види, нигде се експлицитно не помиње пивара, што наводи на два закључка. Први, да је један од објеката служио као пивара, и други, мање вероватан, да се пивара налазила на некој другој локацији у вароши. О самом раду пиваре, процесу производње и врстама пива које је производила - за сада нема историјских података.

\section{Кнежева пивара 1840-1935.}

Следећа пивара отворена у Београду била је Кнежева или Велика пивара, коју је подигла кнегиња Љубица Обреновић, због чега се она у прво време звала и Ђубичина йивара. ${ }^{16}$ Изграђена је највероватније током 1840/1841. године и налазила се у тадашњем београдском предграђу Сава-махала, на углу данашњих улица Адмирала Гепрата и Балканске. Пивара је била једна велика и дугачка приземна зграда од тврдог материјала, у чијем су се склопу уз део у којем се производило пиво налазиле кафана и велика башта. Као пројектант пиваре помиње се Хаџи Никола Живковић. ${ }^{17}$ Пиво се производило мануелним, ручним радом, варено (кувано) је у примитивним казанима, налик војничким, загреваним на угаљ или дрва. Слад је сушен у лименим бубњевима, а једина замена за људски рад био је коњ, који је покретао долап у којем се млео готови слад. Скувано пиво оставило би се неколико дана да преври у дрвеним бачвама, затим би се преточило у буриће из којих је ишло у продају. ${ }^{18}$

Кнез Михаило Обреновић је 8. августа 1841. године затражио да се иривайној економији књажеској, на йивару gа йривилеіија за 15 іоонна, с йим gа ће она

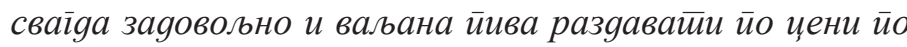
којој и земунска йакова буgе. ${ }^{19}$ Министарство финансија је 18. августа спровело молбу Државном савету с препоруком да се тражена привилегија не одобри из два разлога:

1. Иако Кнежева йивара велељейијем својих ӣосӣројена йревасхоgи Вајнхайаловој, ийак се она иррвом не може назватии затио итио је Вајнхайалова gве іолине раније йочела раяитии.

2. У Беоїраяу йостиоје яве властии, срйска и ииурска. Каg би Кнежевој йивари gао иовлашћени йоложај за 15 іо оина, ко јамчи gа се не би нашао неки Турчин који би хйео йоgићи иичвару и нико му йо не би моїао сйречити . $^{20}$

Државни савет је спровео овај извештај кнезу 6 . септембра и наведеним разлозима додао и ове:

1. По ирравилу яржава gаје иривилеїје са искључивим ирравом онима само вешйацима оg иняуситрије

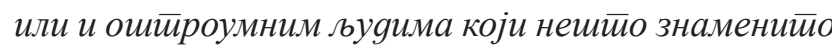
за ууобности или бољи развитак човечијеї животиа йроизвеgy.

2. Каg би Кнежевој ииввари яали искључииеељно ирраво и завео монойол иивварски, ийак се не би мойла gати иривилейија у иравом смислу. Пиварски йосао је обичан и оg сииарина йознати. Вајнхайалова йивара сииворена је ирре кнежеве и она се силом не може зативорийи. Истио йако се увоз сиираних иива не може забранитии. Давањем иривилейије ни-

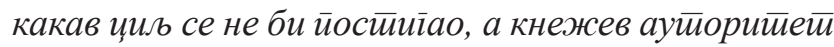
би имао шитеиее. Најзад Државни савет и ово напомиње: Пивара Ваше Свеилостии коg онаке своје йиварске и остиле лаїоgе и коg свої имућстива gоистиа ће за gуіоо време иривилеіију имайи, ийо ће само собом свакої слабијеі конкуренйа искљу-

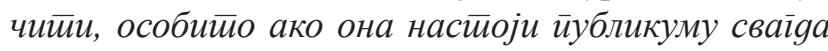
gобра и нейреиеевена ӣива gа їойови и изgаје. ${ }^{21}$

Кнез Михаило је за управника пиваре поставио Константина Хадију Млађег 22 , познатог земунског трговца и школованог пиварског мајстора. Хадија је дужност управника обављао од 1. јануара 1841. до 30. јуна 1842 . године. ${ }^{23}$ 
Највероватније потакнут тешким унутрашњим политичким стањем, кнез Михаило Обреновић обуставља производњу и највероватније након 30. јуна 1842. године, до када је њен управник био Хадија, почиње да издаје пивару под закуп. Постоје два записа о првом арендатору пиваре и она су међусобно контрадикторна. По М. Ђ. Милићевићу, први закупац био је Риста Периповић ${ }^{24}$, трговац пореклом из Старог Влаха, који је пиво ирроизвеgено у обреновићевској йивари слао Вучи-

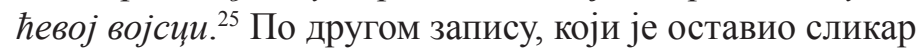
Стеван Тодоровић, исте године закупац пиваре био је Стеван Тодоровић (Поповић), његов рођени стриц истог имена и презимена. Он наводи да је током школског распуста 1842. године боравио код стрица у Београду и оставља интересантан опис како се продавало пиво: $3 a-$ иамитио сам gа сам раgо као дечко раяио с разносачем иива. Јеgном дошавши на Зелени венаи стила су кола на месйу ìge је саgа срушена кућа Сиеве М. Балабана. На иелом ирросйору Зеленої венца била је сйална бара, а йреко ње на gруїој ситрани се налазила механа. Тај механиија на воgи имао је чамац који је, каgа смо ми сииийли, иррешао на нашу стирану и иримио бечку иивва. ${ }^{26}$ Као што се види у оба записа се наводи 1842. година и два различита арендатора, што је мало вероватно, а проценити који је исказ тачан врло је тешко. С обзиром на то да су оба забележена након 50 и више година од времена које описују, није немогуће да се некоме од њих поткрала грешка, а и могуће је да је издавање пиваре у закуп започето раније, током 1842. године.
Након свргавања кнеза Михаила с власти, појавио се проблем плаца на којем је пивара изграђена. Нове власти су тврдиле да је пивара подигнута на државном плацу, тј. да је кнегиња Љубица изградила пивару без ичијеі $\bar{u} и \bar{u} a-$ юа. Убрзо је покренут спор између Обреновића и државе око закупа пиваре и поменутог земљишта, који је коначно решен тек 1860 . године у корист Обреновића. ${ }^{27}$ Без обзира на спор, са издавањем пиваре је настављено и њен следећи познати закупац био је Стеван Аџић, који је пиваром управљао највероватније током 1843/1844. године. Њега крајем 1844. године наслеђује Тома Поповић, током чије управе је дошло до великог пожара у пивари, фебруара 1845. године. Пожар је избио у штали у којој се на тавану налазило сено и проширио се на део пиваре до тобџијске касарне, у којем се производило пиво. Пивару је од потпуног уништења спасило то што јој је кров био напола пресечен (раздвојен), те се пламен није могао пренети на другу половину зграде. Закупцу Поповићу причињена је огромна штета, јер је у пожару изгорело 10.000-12.000 ока жеженог јечма, 10.000 чистог јечма спремљеног за пиво, 20 кола сена, један момачки кревет, један сат и све калфине ствари. Приликом истраге узрока пожара, Тома Поповић и његов слуга Јанко Стаменковић, пореклом из Лесковца, изјавили су да нису ништа необично приметили, али закупац сумња да је у избијање пожара умешан бивши арендатор Стеван Аџић. Међутим, полиција је сумњала на слуге које су то вече спавале у пивари: Мађара Пала Антона, који је био задужен за коње, Немца Христијана, воденичара Давида Јовановића и Јохана Арона.
Сл. 2.

Кнежева иичвара йочейком ХХ века (Музеј іраga Беоїраga)

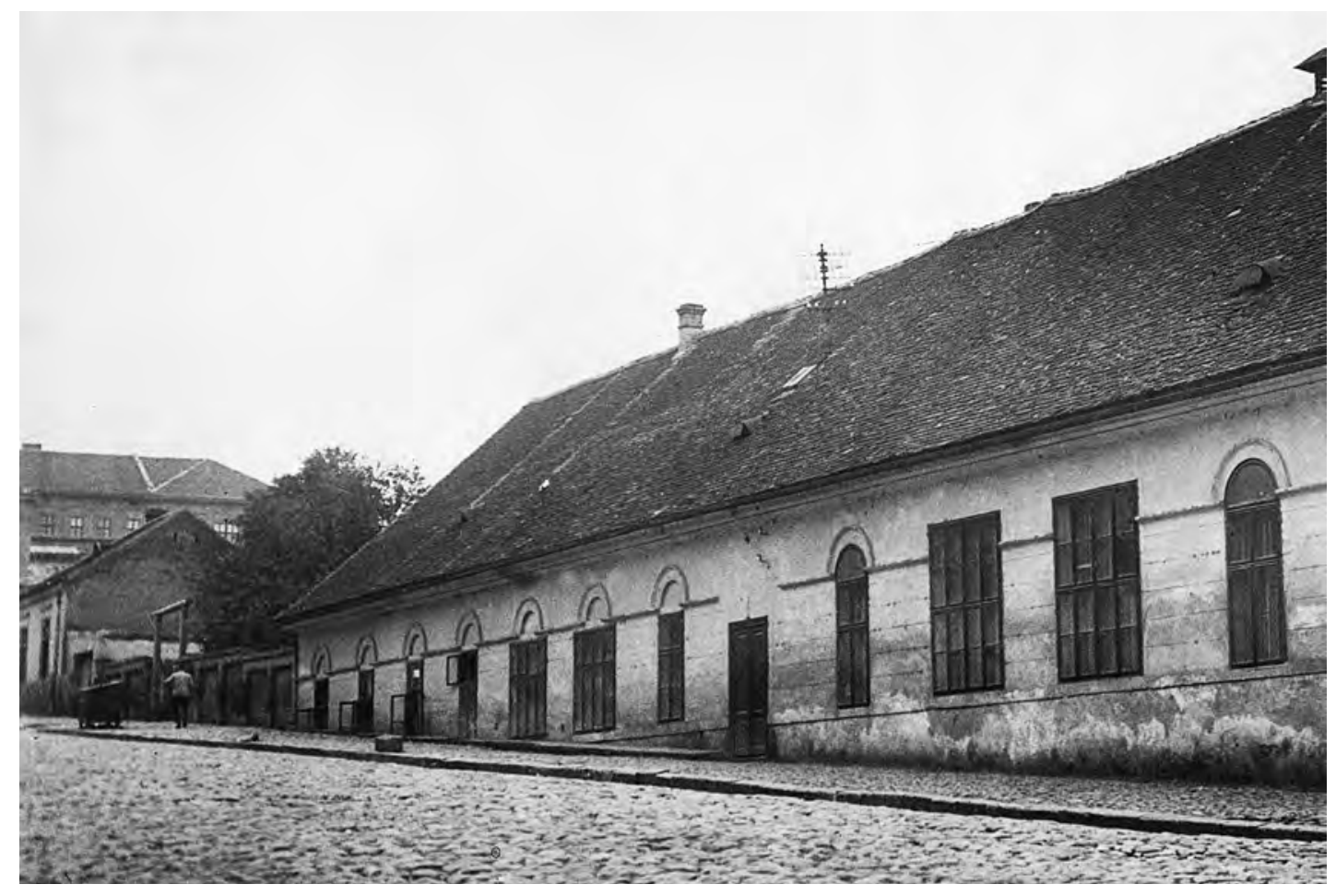

СПОМЕНИЧКО НАСЛЕЪЕ 24 
Судски истражитељ наводи да су они те вечери били толико пијани да о себи скоро, осим Мађара, нико ништа није знао, док су са друге стране они одлучно негирали да имају икакве везе с пожаром. ${ }^{28}$ Како се завршила истрага, није познато и убрзо је расписан оглас у којем се позивају заинтересовани зидари да дају понуду за поправку оштећеног дела пиваре, након чега је нешто касније пивара санирана и наставила са радом. ${ }^{29}$ У обнову пиваре и њено покретање у рад хтео је да се укључи и Константин Хадија Млађи. Он је у писму Вуку Караџићу од 18. марта 1845. године изнео да жели да се врати у Београд и да поново покрене производњу у допола изгорелој пивари. Његову жељу требало је да Вук Караџић изнесе Милошу Обреновићу, од ког се очекивало одобрење за Хадијин повратак и поправку пиваре. До тога није дошло пошто га је кнез Милош узео за свог личног секретара, тако да се Хадијина пиварска делатност заувек завршила. ${ }^{30}$

О закупцима пиваре до 1865. године за сада нема конкретних и поузданих података, али зна се да је кафану у њеном склопу 1851. године преуредио и узео у закуп гостионичар Сима Живковић Биргер. ${ }^{31}$ Такође, у једном писму из 1852. године помиње се Ђока Савић, пивар из Београда, али се данас о овом човеку ништа не зна, те да ли је евентуално и коју од тадашњих београдских пивара држао у закуп. ${ }^{32}$ У попису Београђана који поседују коње, 1854. године, забележен је и Франц, пивар у Великој пивари, који поседује четири коња с колима. Овај пиварски мајстор је највероватније био њен арендатор, али се нажалост не може тачно одредити и временски период у којем је то био. ${ }^{33}$ Године 1856 . кафану под аренду у наредних шест година узима Леополд Рајхел. На основу текста једног огласа из 1862, у коме Рајхел и његов ортак Шмауз отварају стовариште пива у близини Велике пиваре, може се само претпоставити да су сем кафане у закуп држали и пивару. У огласу између осталог наводе ga ће као gо саgа йако и оg саgа своје йошйоване му-

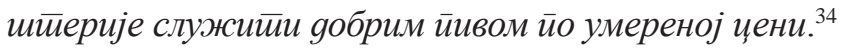

Јануара 1865. године, Кнежеву пивару у закуп узима Игњат Вајферт, власник Панчевачке пиваре. ${ }^{35} \mathrm{O}$ раду пиваре током Вајфертове управе нема много сачуваних докумената, али се зна да се у њој производило светло и тамно мерцен (мартовско) пиво, да производња није могла бити већа од неколико хиљада хектолитара пива, те да је пивара продавала и шпиритус. ${ }^{36}$ Продаја пива из Кнежеве пиваре ишла је добро, а како је производња била мануелна - нису се могле произвести значајније количине, које би задовољиле потражњу на тржишту. И. Вајферт је крајем шездесетих година XIX века од београдског адвоката Петра Марковића купио плац Смутековац, с малом кафаном-пивницом, у намери да изгради нову модерну пивару на парни погон. Он је Кнежеву пивару држао у закуп до 1873. године, када је отпочела рад прва модерна пивара у Србији, коју је изградио са својим сином Ђорђем, Прва српска парна пивара Ђорђа Вајферта. Почетак рада нове пиваре означава и крај производње пива у Кнежевој пивари. ${ }^{37}$

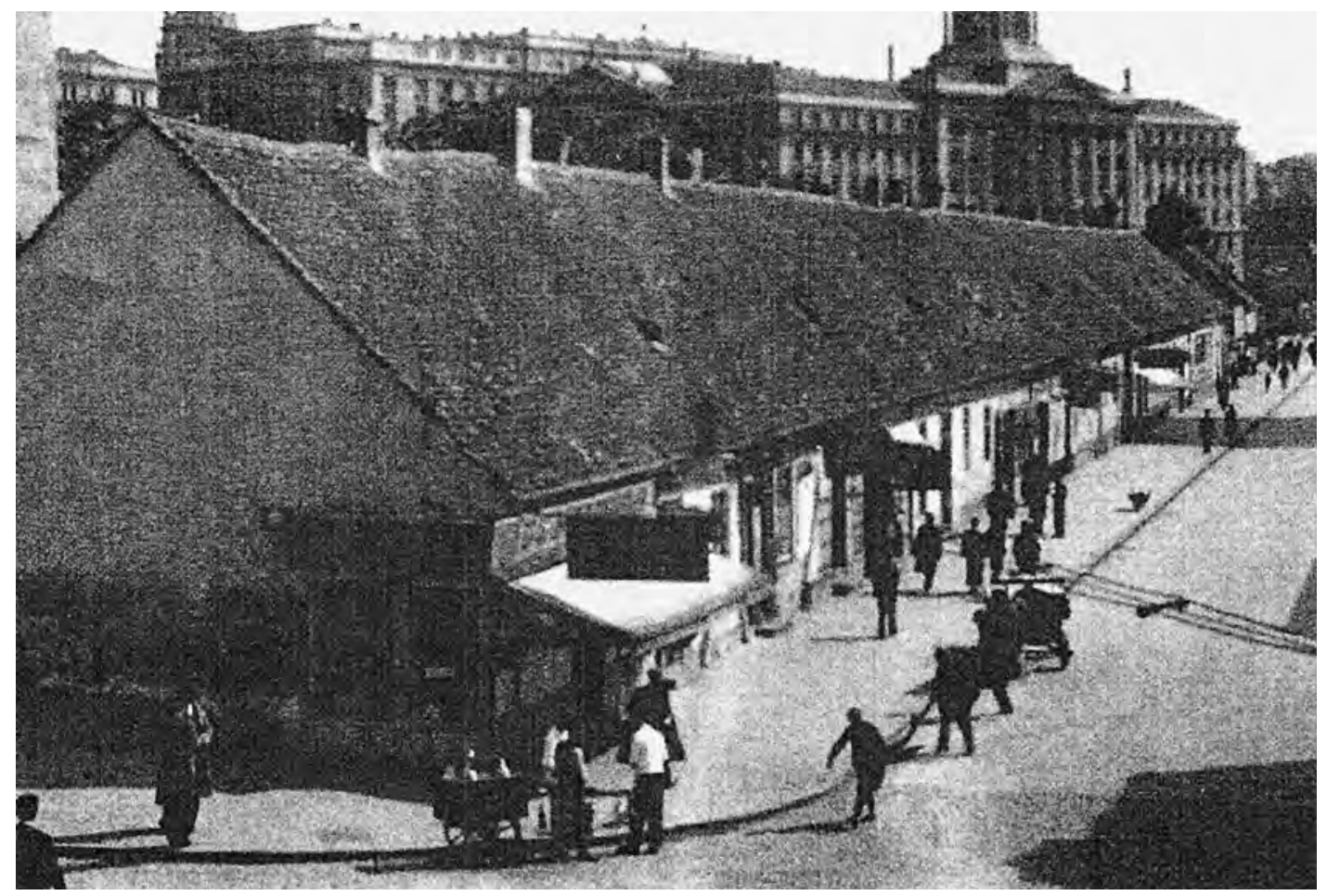

Сл. 3.

Кнежева ииввара 20-их іояина $Х X$ века (В. Голубовић, 'Механе и кафане Сйарої Беоїраgа', Беoі̄pag, 2007) 


\section{НЕНАД ЛУКИЋ}

Кнежева пивара нема историјски значај само у области пиварства већ и у културним и политичким дешавањима у Србији тога времена. Због своје пространости, примила је народне посланике Светоандрејске скупштине 1858. године, након које је Милош Обреновић враћен на власт у Србији. У њој је одиграна прва позоришна представа у Београду, у извођењу једне дилетантске немачке позоришне групе, да би у периоду од 1857. до 1862. године у њој представе играла и дилетантска позоришна група Анастаса Јовановића под називом Друшииво срискоі̄ йозоришӣ $а$. Након престанка с производњом пива 1873. године, она је имала више различитих намена, да би 1882. променила име у Краљева пивара и прешла у власништво краљице Наталије Обреновић. Касније, крајем XIX и почетком XX века, била је седиште Официрске задруге, затим Аукционог фонда, да би је коначно 1912. године за 615.000 динара од краљице Наталије откупила Прометна банка. ${ }^{38}$ Пивара је срушена 1935 . године, када је преуређиван тај део Београда. ${ }^{39}$

\section{Милутиновићева пивара}

До сада није било познато постојање ове пиваре и њено једино помињање у историјским изворима за сада је у тексту објављеном у Србским новинама из 1846. године, у којем се наводи: Како вияимо и ове ће іолине Беоіраg мноіим новим зяанијима битии улейшан. До саg смо имали јеуну йивару, а саg су се јошй gве саїраgиле, оg кои јеgна Г. Милуишиновићева већ раgи. ${ }^{40} \mathrm{O}$ ком Милутиновићу и о којој пивари се ради, данас је тешко одгонетнути. Новинар у тексту износи још два битна податка, да је до те, 1846. године постојала само једна пивара, под којом највероватније мисли на Кнежеву, а друга наведена пивара у изградњи може бити пивара Стевана Тодоровића, познатија као Кумануgина иичвара или можда Филитова йивара.

\section{Пивара Стевана Тодоровића, потоња Куманудијева пивара}

Највише података о овој пивари оставио је познати београдски сликар Стеван Тодоровић ${ }^{41}$, који у аутобиографији пише да је његов стриц Стеван Тодоровић (Поповић) у другој половини четрдесетих година XIX века изградио пивару на Јалији ${ }^{42}$ на Дорћолу. Сликар који је тада живео у Бечу морао се по слому револуције 1849. године преселити код стрица, који га запошљава у пивари. Тодоровић пише: Ogмах йо доласку он ме је йровео йо оgељењима їgе се йриуіотиовљава иииво, чинећи ми йонуgе и убеђујући ме како би било иробитачно gа се оgам

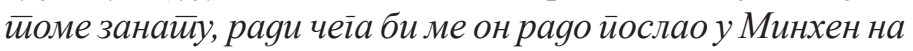
изучавање. Како је йо смрйи моїа оиа сиирии био, йореg моје gобре мајке најбољи ситаралач за моје gаље образо-

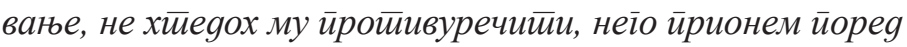

йиварской калфе на учењье тиако да сам за 2-3 месеияа био у стиағу сам куватии иииво. ${ }^{43}$ Иако се обучио за пиварског мајстора, Тодоровић није остао у овом послу. Једном приликом када је његов стриц ушао у калфину собу и

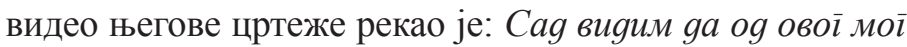
синовца неће битии иичвар. Стриц је умро 1850. године и, како није имао наследника, он је у тестаменту за пивару и имање огласио наследнике синовца Стеву и синовицу Драгу. Сликар даље наводи да му је пивару отео банкер Јован Кумануди у дослуху с градским пашом, уз свесрдну помоћ београдског адвоката Познановића. Разлог за одузимање пиваре је био тај што је Кумануди тврдио да сликарев стриц није могао купити турско земљиште, те je због тога успео да поништи купопродајни уговор и постане власник поменуте пиваре. Тодоровићу и његовој сестри је на крају од стричеве пиваре припало 100 дуката и то од продатих коња и пиварског алата. ${ }^{44}$ Кумануди ${ }^{45}$ није имао озбиљније амбиције да се бави пиварским занатом те је врло брзо пивару почео да издаје у закуп. О њеном раду се такође мало зна и за сада једини посредан податак који указује на то да је у њој произвођено пиво потиче из 1854. године. У попису Београђана који поседују коње налази се и извесни Франц, пивар на Дунаву. Поменути је поседовао четири коња са колима, који су служили за транспорт пива по Београду и превоз неопходних сировина. ${ }^{46}$ На основу овог записа не може се поуздано утврдити да ли је он био арендатор Куманудине (или Куманудијеве) пиваре, што је врло могуће, као ни да ли су он и већ помињани Франц пивар у Великој пивари иста или различита особа. Поред пиваре, Кумануди је подигао и кафану-пивницу која је била од слабог материјала, а састојала се од две собе, кујне и подрума. Пивара се није дуго одржала и већ почетком шездесетих година претворила се у рушевину, служећи као топоним за оријентисање Београђанима. ${ }^{47}$

\section{Филипова или Мала пивара 1850-1888.}

Један од историчара који се бавио индустријским развојем Србије Никола Вучо пише да је расходоване уређаје из Вајнхаплове пиваре користио Филип Ђорђевић за опремање пиваре коју је изградио у доњем делу Цетињске улице. ${ }^{48}$ Тачну годину изградње и почетка рада пиваре тешко је утврдити и за сада се прихватају подаци из хронолошки каснијег времена у којима се наводи да је пивара основана 1850. године. У попису градских механа из 1860. године наводи се да је Филип Ђорђевић ${ }^{49}$ отворио исту 1845 , тако да је 1850 . година приближно тачна..$^{50}$ Поменута кафана је била до саме пиваре, направљена од набоја и цигле са пет соба, две кухиње и подрумом, а у закуп ју је држао Ђорђе Димитријевић, који није плаћао аренду, већ је точио под рачун пиво из Филипове пиваре. ${ }^{51}$ Пивара је била у ствари једна површински већа једноспратна 
зграда с таваном, такође слабо технички опремљена. Производња је била заснована на ручном раду и сводила се на обичан начин превирања јечма превртањем и заливањем воде, те је грејањем добијан слад, а хидролизирани скроб куван с хмељом и остављан да ферментира. Због мањег капацитета, који није био већи од неколико хиљада хектолитара, и мањег простора од Кнежеве пиваре, она је називана и Малом пиваром. ${ }^{52} \mathrm{O}$ раду Филипове пиваре нема много података, али се зна да је у њој 1861. године радио пинтер Данил Видман са још тројицом колега. Такође, нешто раније, 1854. године у већ помињаном попису Београђана који поседују коње помиње се и извесни Јозеф Литнејер, пивар, који поседује два коња са колима и који се можда може повезати са овом пиваром. ${ }^{53}$ Из овог периода забележен је интересантан податак да је Управа града Београда 1861. године забранила развоз пива свим пиварима у празничне и недељне дане по Београду. ${ }^{54}$ Ђорђевић је самостално водио пивару до 1871. године, када на иницијативу групе имућних београдских трговаца и механџија с радом започиње Прво српско акционарско пиварско друштво у чији је састав ушла и његова пивара. Организовање друштва започето је крајем 1870. и почетком 1871. године уписом акција оних људи који су желели да постану његови акционари. До 13. фебруара 1871. године пријавило се њих 41 и то: Илија Милосављевић Коларац, Филип Ђорђевић, Милан Ж. Ђорђевић, Божа Г. Панић, Сима Д. Миленковић, Јаков Бајлони, Михајло Ристић, Браћа Ивковић, Павле Ђорђевић, Браћа Петровићи, механџије, Јанко Баша, Никола Џанга, Дума Ђ. Хаиме, Д. С. Николић, Јован Дилбер, апотекар, Наун С. Науновић, Милан Г. Филиповић, Драгољуб С. Поповић, Димитрије С. Јовановић, Јован Х. Димитрије Рошу, Христодуловић и Михајловић, Коста Лазаревић, Прокопије Јовановић, А. Абдулић и друг, Рашић и Спиридоновић, Моша Меторе, Лука Н. Величковић, Велимир Протић, Коста Стефановић, В. Д. Грујдић, Мијаило Ј. Никетић, Н. Д. Прапорчетовић, Стева Добривојевић, Д. Ђорђевић, Јован Митровић, Стева Д. Видаковић, Петар Р. Јовановић, Драго Видаковић и Тодор Костић. По статуту друштва, одобреног од стране министра народне привреде 14. маја 1871. године, уписани капитал износио је 50.000 дуката цесарских, подељен у 5.000 акција, вредности од 10 дуката за сваку. ${ }^{55}$ Упис деоничарских акција започео је 20. јуна 1871. године и вршен је код Прве српске банке, Кредитног завода, Београдског абаџијског друштва, Михајла Ристића, механџије, Тодора Костића, механџије, у пивници Игњата Бајлонија и у Филиповој пивари. ${ }^{56}$ Акције су уписиване у више циклуса: први је износио 1 дукат на дан почетка уписа акција, други је износио такође 1 дукат који се имао уплатити дан пре почетка пословања друштва, а осталих 8 дуката сукцесивно у наредном периоду, искључиво на позив Управног одбора, максимално 2 дуката по циклусу уписа. ${ }^{57}$
На оснивачкој скупштини одржаној 1. августа 1871. године изабран је Управни одбор друштва, чији је председник постао Сима Д. Миленковић, а чланови: Тодор Костић, Драгољуб С. Поповић, Филип Ђорђевић, Велимир Протић, Јован Дилбер, Јаков Бајлони, Јован Панђела и Михајло Ристић. ${ }^{58}$ Друштво је конституисано по тадашњим законским правилима, са Управним одбором, Скупштином акционара и другим друштвеним телима. Чиста остварена добит се делила: пет одсто за резервни фонд, 16 одсто члановима Управног одбора на име награде, три одсто председнику УО на име награде и седам одсто акционарима на име дивиденде. Највећи акционари друштва су били: Јаков Бајлони, Велимир Протић, Игњат Стаменковић, Марко Денић, Петар Ристић, Јован Дилбер, Никола Џанга, Милан Ж. Ђорђевић, Коста Лазаревић, Н. Д. Прапорчетовић, Наун С. Науновић, Рашић и Спиридоновић итд. Број гласова на Скупштини распоређен је према броју купљених акција: 1-4 акција $=1$ глас, $5-10=2,11-20=3,21-35=4,36-50$ $=5,51-75=6,76-100=7,101-150=8,151-200=9$ и преко 201 акције $=10$ гласова. ${ }^{59}$ Друштво је 5. септембра 1871. године откупило пиварску зграду од Филипа Ђорђевића, који је за њу добио одређени број акција. ${ }^{60}$ Иако су један део уложеног капитала акционари уложили за обнову зграда и набавку бољих пиварских постројења, производило се и даље ручним радом те се стога нису могли постићи неки виши производни резултати. ${ }^{61}$ Друштво је свој пиварски посао започело 15. јануара 1872. године, склопивши са Општином београдском уговор за коришћење воде са чесме у Скадарској улици. По овом уговору, пивари је дозвољено да користи воду са горњих чункова скадарске чесме и то само увече од 10 до три сата ујутру, након чега су се са чесми морали скинути чункови који су спроводили воду у пивару. Друштво се уговором обавезало да за коришћење чесме плаћа 12 дуката годишње и то тромесечно унапред у корист сиротињског фонда. ${ }^{62}$

Званична продаја пива Првог српског пиварског друштва почиње 19. марта 1872. године и то у само неколико гостионица: код Симе Миленковића у Турском хану, код Тодора Костића код „Македоније“, код Јована Панђеле код Батал џамије, код Михајла Ристића у Кнез Михаиловој улици и код Игњата Бајлонија и синова. ${ }^{63}$ У прве две године рада, закључно са септембром 1873. године, продато је 8.653 акова ${ }^{64}$ пива за 665.318 гроша и требера ${ }^{65}$ у вредности 21.272. гроша. ${ }^{66}$ Друштво није имало пословне среће, пошто је већ 1873. године отворена најмодернија пивара у Кнежевини Србији, Прва српска парна пивара Ђорђа Вајферта. Колико је она била јака конкуренција, најбоље одсликава оглас друштва у којем се наводи: Уверавамо свакої иријайеља Срйскоі̄

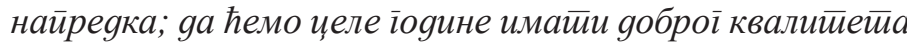


йива, и довољну количину јер је дружина свој раg боље удесила, и јамчи за іорње навоgе - друшитво се узgа gа ће Срйска йублика своме Срйском завоgу иријаиельски оgазвати се, и неће ваљяа увек коg Србина бити, gа је само йуђин у стиағу Србину кайу кројийи. Под појмом туђин највероватније се мислило на Вајфертове и њихову нову пивару. ${ }^{67}$ Иако је потрошња пива кренула узлазном путањом, ракија и вино су и даље били најомиљеније пиће Београђана. Ову тврдњу најбоље илуструје податак да се у 70 механа Теразијског кварта за годину дана попије 5.120 акова вина и 3.135 акова ракије. Када се упореди с продајом пива, види се да се за две године производње истог продало колико ракије и вина у само једном од београдских квартова за годину дана. ${ }^{68}$ Током наредне пословне године, од 1. октобра 1873. до 27. августа 1874, пивара је произвела 150 казана или 5.750 акова и докупила 250 акова страног пива од чега је продато укупно 5.061 акова (2.530 хл) за 379.095 гроша чаршијских. Чиста пословна добит те године износила је 35.063 гроша чаршијска. Добит је мала јер је те године председник Управног одбора Сима Д. Миленковић окривљен за проневеру 273.294 гроша чаршијска, а на крају је и осуђен, додуше за нешто мању суму од 195.000 гроша. Услед овога дошло је и до премене председника Управног одбора Симе Д. Миленковића, кога наслеђује Тодор Костић Нанка. ${ }^{69}$

Друштво је покушало да парира Вајфертовој пивари и у циљу што боље продаје и дистрибуције пива, 10. јануара 1874. године склопило је уговор с Љубомиром Величковићем о продаји и разношењу пива у којем пише:

1. Друшитво усииуйа йрояавање и разношење ииива у вароши Беоіраяу Љ. Н. Величковићу йо ичени коју Уйравни оябор оgреgио буgе, а ирровизион оя акова четиири іроша, а на флаше оg сииоиине оиети ірома 6.

2. Љубомир се обавезује gа ће сваки gан за іойов новаи йиво у канцеларији ярушитвеној йлаћайи и йоиррошаче заяовољитии уљуяном и брзом услуіом.

3. Разноситель Љубомир мора сваїgа увечер уйрави-

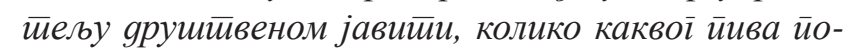
йребује за ияући gан, gа би се без оялаїаға йиво сирремитии мойло, а мушиееријама йо ойреgеленој

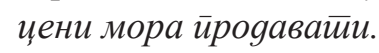

4. Празна бураg и флаше најgаље за месеи яана мо-

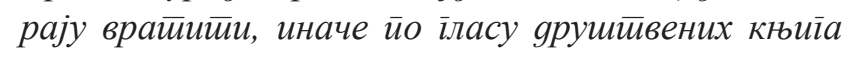
мора безусловно йлайити аков 30 іроша, а йоловаче 20 іроша за флаше 60 йара, а за сиіурносй бу-

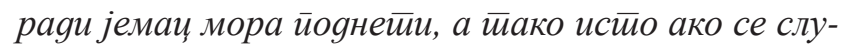
чајно у новиу дружини заяужитии, јемиа йоgнетии

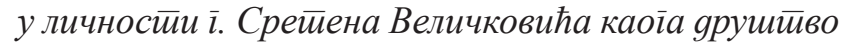
као йакової раяо ӣрима.

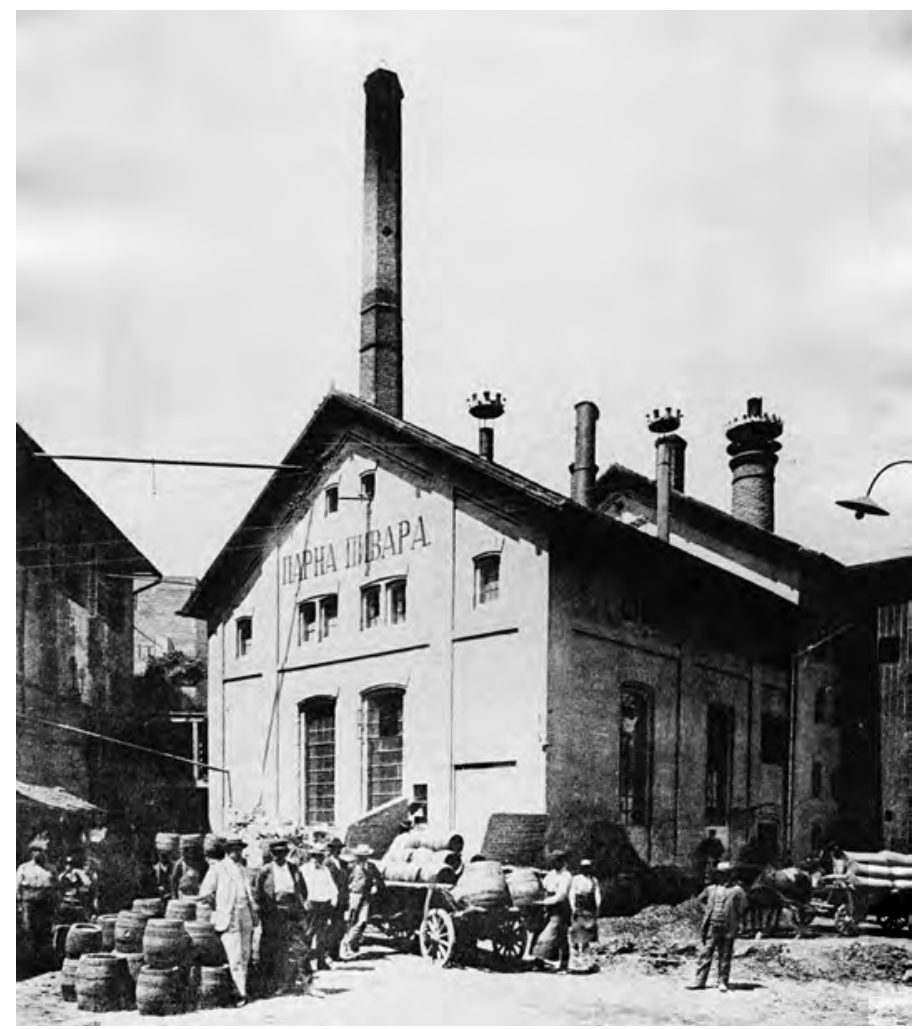

Сл. 4. Мала йивара крајем ХІХ века (Истиоријски Архив Беоїраgа)

5. Уйрава заяржава ӣраво, gа ако се разносач небри-

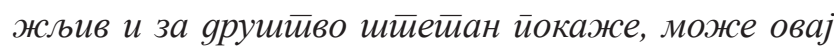
уїовор раскинутии и разносача ояйустиитии без икаквої разлоїа.

6. Ако би йак разносач хйео рая найустиитии gужан је

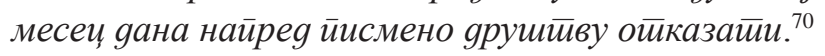

Мала пивара је те 1874. године производила две врсте пива: лагер пиво и дупло и обично мерцен пиво. Лагер пиво је коштало 62 гроша за аков, обични мерцен 72 гроша, дупли мерцен 82 гроша, а једна чаша 0,60 пара. ${ }^{71}$ У наредној пословној години од 27. августа 1874. до 1. септембра 1875. године скувано је 126 казана. Уз остатак од 891 аков из претходне године, укупно је продато $7325^{1 / 4}$ акова, 441 је попијен у пивари, док је 218 дато у име провизиона. За продато пиво добијено је укупно 572.000 гроша. $^{72}$ Међутим, у наредних пет година, до 1880, више нису одржаване редовне скупштине. Поједини акционари су се због овога бунили, али је то правдано ратовима с Турском 1876-1878. и финансијском кризом. Услед оваквог стања, на Скупштини одржаној 1880. године одлучено је са 262 гласа за и 28 против да се прода пиварска зграда. Овим се завршава и пиварска производња друштва, које од 1883. године улази 


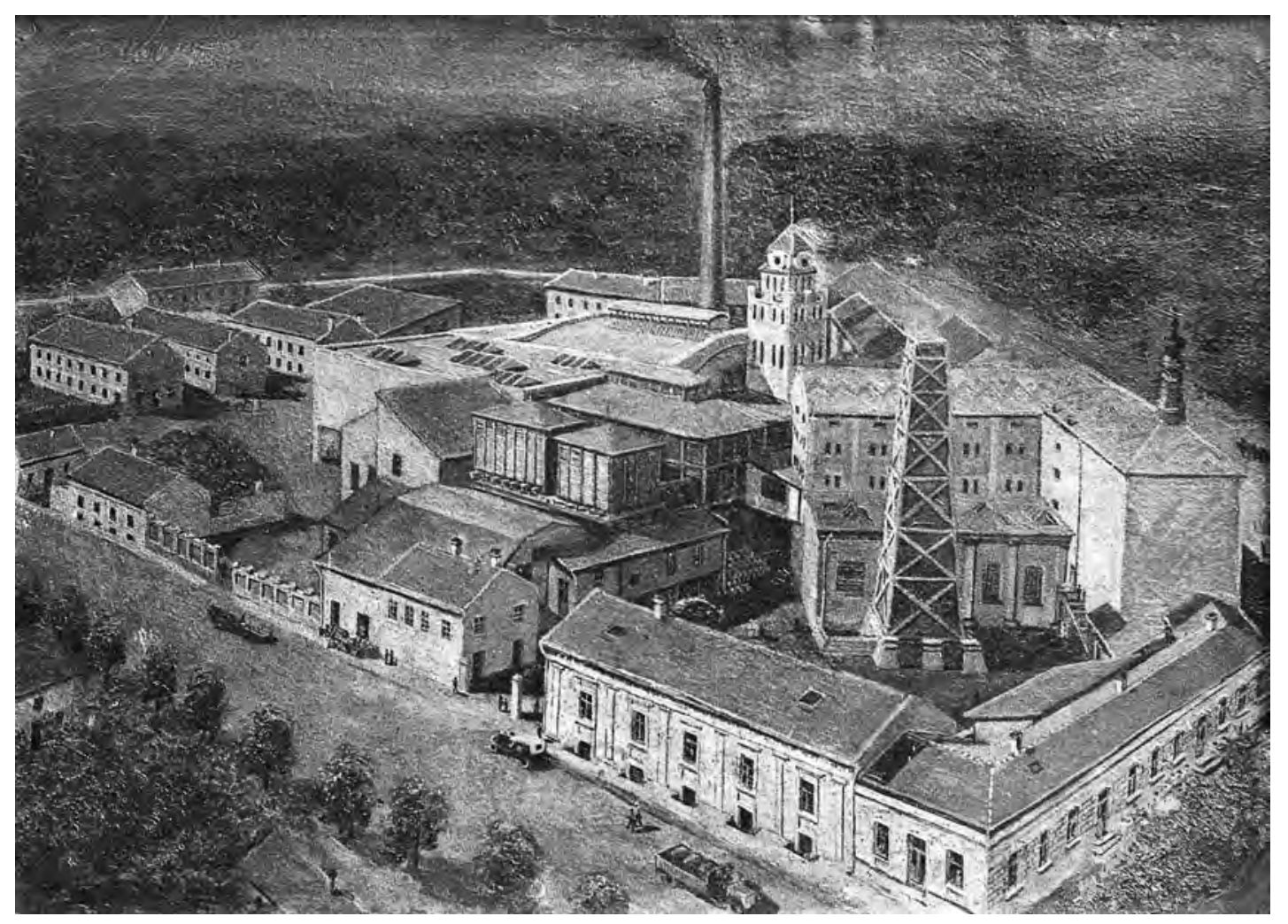

Сл. 5.

Мала йивара йочейком

20-их іооина ХХ века

(Истиоријска

gокуменимаиија БИП)

у процес ликвидације. ${ }^{73}$ Како Вучо наводи ${ }^{74}$, Друштво је пивару продало 1881. године фирми „Игњат Бајлони и синови“, да би је они 1883. продали своме пашеногу Јовану Брабецу. Током следећих пет година Брабец је извршио веће измене на Филиповој пивари и између осталог 1884. увео у процес производње парну машину, чиме је окончан период ручне производње пива у Београду. Брабец је након четири године рада, почетком 1888 , поново продао пивару фирми „Игњат Бајлони и синови“, која је свој пиварски посао званично започела 29. фебруара 1888 . године. ${ }^{75}$

Најстарији податак о простирању и изгледу Мале пиваре може се видети на плану града Београда који је саставио инжењер Стеван Зарић 1878. године. На том плану, земљиште које затварају Скадарска и Цетињска улица према Видинској улици заузима имање означено као Мала пивара. Из плана се види да је комплекс дугачких зграда стациониран око дворишта према Скадарској улици и једна зграда се налазила на самом углу, у којој је била Филипова механа коју је под закуп држао Димитријевић. ${ }^{76}$ Након преузимања пиваре у власништво, фамилија Бајлони ју је додатно модернизовала тако да је до 1896. године уложено 245.000 у пиварске зграде. Уз пивару је 1892. изграђена и гостиона код „Мале Скадарлије“, данашња кафана „Скадарлија“, која је наставила традицију Филипове пивнице. Из једног списка за држање забава види се да је у гостиони само у 1897. години одржано шест забава, које су приређивали Певачко друштво „Војислав“, Вечерња занатска школа и радници Бајлонијеве пиваре. Пивара је наставила да ради и током 20. века, да би коначно 1947. године из власништва фамилије Бајлони прешла у власништво државе. Тада мења име у пивара „Београд“, под којим самостално ради до 1963. године, када заједно са Вајфертовом пиваром формира ново предузеће Београдска индустрија пива и безалкохолних пића (БИП). У оквиру БИП-а послује до 2005. године, када је на аукцији продата страном партнеру, који није наставио с производњом пива. Иако је решењем Завода за заштиту споменика културе града Београда бр. 322/2 од 28. 7. 1967. године Мала пивара у склопу урбане целине Скадарлија стављена под заштиту Завода, њене зграде се данас налазе у веома лошем и руинираном стању. ${ }^{77}$

Ненад М. Лукић, историчар

А. Д. Београдска индустрија пива, слада и безалкохолних пића nenad.lukic@bip.co.rs 


\section{НАПОМЕНЕ:}

1] Новаковић 1911: 151-152.

2] Шабановић 1964.

3] АC, ЗМП, 7920. На полеђини овог документа накнадно је дописано: Јеgни оg највећих йивара била су браћа Кейиш која су се из Темишвара доселила у Беоїраg. Године 1724. gолази gо монойолисањ в варењ а йива и њеїа gобијају браћа Кейиш за 200.000 фо-

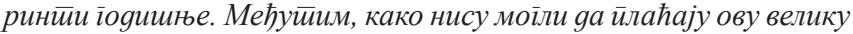
йрошарину, аусииријска уйрава је оgузела ииивару у којој се йаgа нашло 137.201 йасиве и 119.506 фориниии акиииве. Није познато одакле је овај податак преузет, али се браћа Кепиш помињу на неколико места у Поповићевој публикацији. Поповић 1935: 163, $168,170,183,187,192,193,222,223,245$.

4] Милићевић 1902: 42.

5] Голубовић 2007: 256 .

6] Вучо 1981: 273.

7] $\mathrm{AC}, 3 \mathrm{MП,} 7920$.

8] AC, КК, Шабачка нахија, XXXVIII, 1575. Током прве две године Вајнхапл се бавио градњом прве правитељствене воденице у Србији у Параћину. Воденица је саграђена испод старе коју је књаз откупио од лебанског господара Омера. Интересантно је истаћи да је током њене градње Вајнхапл дошао у сукоб са старешином среза параћинског целим капетаном Татар Богданом Ђорђевићем. Након изградње воденице, кнез Милош Обреновић га је 1838. године саветовао да у Крагујевцу од турске џамије сагради пивару, али се он ипак одлучио за Београд. Видети више у: Петковић, Ђ. (2008), Јохан Вајнхапел гради млин у Параћину 1837/8. године, Корени VI (Јагодина).

9] АC, КK, Крагујевачка нахија, XV, 2145.

10] АС, ЗМП, 7920; АС, ДС, 1840, ролна 77, документ 242.

11] АС, ДС, 1840, ролна 77, документ 242.

12] Ранковић 1941.

13] Перуничић 1970: 214-217.

14] Хват $=1,896$ метара.

15] Србске новине, 3. септембар 1848: 528; Исйо, 15. октобар 1848: 619.

16] АС, ДС, 1843 , ролна 95, документ 148; 1856, ролна 205, документ 84.

17] Голубовић 2007: 231.

18] Grgašević 1924: 98-99.

19] Ранковић 1941.

20] Истио

21] Исйо.

22] Породица Хадија потиче из Мелника у грчкој Македонији, а њен родоначелник у Србији био је Константин Хадија Старији, који се оженио Франциском, најстаријом ћерком Себастијана Крајцајзена, пивара из Земуна. Његов син Константин Хадија Млађи (1809-1888), као 20-годишњак је стекао еснафско писмо о изученом пиварском занату код бечког пивара Нојлинга. Ради даљег усавршавања провео је седам месеци и три недеље у пивари кнегиње Марије Леополдине под надзором пиварског мајстора Франца Бема. Потом је боравио код пиварског мајстора Франца Шрота у Грацу од 26. јуна до 18. августа 1830. године. Године 1834. жени се Јеленом - Јелком, кћерком Јеврема Обреновића, и до краја живота остаје у тесним пословним и пријатељским везама са Обреновићима.

23] Јовановић 2004: 243.

24] Милићевић наводи да је Периповић пореклом Рудничанин, али се на основу података из нешто каснијег Шемайизма
Кнежевине Србије види да је пореклом из Старог Влаха и да је по професији трговац.

25] Милићевић 1902: 28. Ово је врло интересантан запис, пошто је управо после Вучићеве буне кнез Михаило 25. августа 1842. године абдицирао те напустио Београд и Србију.

26] Тодоровић 1951: 28-29. Бечка - буре.

27] АС, ДС, 1843, ролна 95, документ 148; 1856, ролна 205, документ 84; Вучо 1981: 275.

28] Перуничић 1970: 177-179.

29] Србске новине, 11. август 1845: 256.

30] Јовановић 2004: 243.

31] Србске новине, 10. март 1851: 110.

32] Веселиновић 1965: 187.

33] Перуничић 1970: 311.

34] Србске новине, 8. јануар 1863: 10; Перуничић 1970: 410.

35] Србске новине, 4. март 1865: 98.

36] Исимо, 11. март 1871: 138.

37] Лукић 2014: 82-83; Фамилија Вајферт пореклом је из Вршца, док им је даља старина из Горње Аустрије, област око града Линца. Предак Вајфертових звао се Филип, а његов унук Георг (1798-1887) 1841. године сели се у Панчево са супругом Магдаленом и синовима: Игњатом (1826-1911), Георгом, Карлом и Валентином. Игњат је основе пиварског заната научио од ујака и додатно их проширио у разним пиварама у западној Европи. Године 1847 . од свог ујака је откупио панчевачку пивару и успешно радио у њој наредних година. Убрзо се жени Аном Сајц из Вршца и са њом добија синове: Георга (1850-1937), Хуга (1852$1885)$ и Стефана и кћерке: Ану, Паулу и Магдалену. Након смрти млађег сина Хуга 1885. године, поново преузима руковођење пиваром у Панчеву, у којој остаје до своје смрти почетком 1911 године. Видети више у: Stanić Vajfert, В. (2007), Vajfertovi: hronika familije Vajfert u Vršcu i Pančevu. Beograd: B. Stanić Vajfert.

38] Полийика, 5. јун 1912: 2.

39] Голубовић 2007: 230.

40] Србске новине, 7. април 1846: 111.

41] Стеван Тодоровић (Нови Сад, 13. април 1832 - Београд, 22. мај $1925)$ био је познати српски сликар и зет Матије Бана.

42] Део Дорћола од Видинског сокака до Дунава.

43] 1951: 30 .

44] Поповић 1951: 30.

45] Породица Кумануди је грчког порекла из Трапезунта, а у Србију се доселила из Једрена 1829. године. Јован Кумануди је био йравииелстивени банкер, тј. вршио је плаћања у име српске државе углавном исплату данка Порти и замену оштећеног новца из државне благајне. Поседовао је више некретнина у Београду: неколико кућа, међу њима и познату кафану „Грчка краљица“, као и доста обрадиве земље у Макишу и неким другим крајевима Кнежевине Србије. С Миланом Миловуком је издавао Тріовачке новине у периоду 1861-1862. године. Оженио се Хризантом Зинзифа, родом из Битоља, са којом је имао Андрију, Димитриja, Милеву, која је наследила „Грчку краљицу“, и Катарину. Јован Кумануди је умро у Београду 1866. године. Видети више у: Костић Миливоје М. (1994), Усйон Беоїраgа, књ. 1, Београд.

46] Перуничић 1970: 311.

47] Костић 1998: 119.

48] Вучо 1976: 92. 


\section{БЕОГРАДСКЕ РУЧНЕ ПИВАРЕ У ХІХ ВЕКУ}

49] О Филипу Ђорђевићу се данас мало тога зна. Познато је да је у Србију дошао из суседне монархије и да је умро крајем седамдесетих година ХІХ века. Видети у: ИАБ, УГБ, година 1880, кутија 1845, документ 133.

50] АС, МНП, Пф 10, p. 1/1887; Беоїраg у слиции и речи 1892.

51] Перуничић 1970: 383.

52] Вучо 1981: 275.

53] Перуничић 1970: 310 .

54] Милан Ристовић и др. 2005: 383.

55] АС, МНП, Пф 10, p. 1/1887.

56] Србске новине, 23. јун 1871: 380.

57] АС, МНП, Пф 10, p. 1/1887.

58] Србске новине, 5. август 1871: 481.

59] АС, МНП, Пф 10, p. 1/1887.

60] Србске новине, 16. септембар 1871: 582.

61] Вучо 1976: 93.

62] Перуничић 1970: 746.

63] Србске новине, 16. март 1872: 192.

64] Аков - 50 литара.

65] Требер је пиварски нуспроизвод, тј. прокувани слад, који се користи у сточној исхрани.

\section{ЛИТЕРАТУРА:}

Беоіраg у слиции и речи (1892), Будимпешта.

Веселиновић, Р. (1966), Грађа за истиорију Беоїраga og 1806 go 1867, књига 1, Београд: Музеј града Београда.

Вучо, Н. (1976), Бајлонова пивара у Скадарлији 1880-1941, Гоguшњак ірраqа Беоїраqа XXIII (Београд): 93-96.

Вучо, Н. (1981), Развој иняусйрије у Србију у XIX веку, Београд: САНУ.

Голубовић, В. (2007), Механе и кафане стиарой Беоїраgа, Београд: Службени гласник.

Grgašević, J. (1924), Istorija industrije Srbije i Crne Gore, Zagreb: Jugoslovenski Lojd.

Đorđević Jovanović, J. (2004), Hadije i Srbi, Prilozi za književnost, jezik, istoriju i folklor vol. 70, br. 1-4 (Beograd): 237-257.

Илић, С. и Јерковић, С. и Булајић, В. (2010), Ђорђе Вајферй : визионар и йреі̆алаи : лична и пословна илустрована биографија (1850-1937), Београд: Народна банка Србије.

Костић, М. М. (1998), Усйон Беоїраgа : Послови и дани трговаца, привредника и банкара у Београду XIX и XX века, Београд: Библиотека града Београда: Историјски архив Београда: Завод за заштиту споменика културе града Београда.

Лукић, Н. (2014), Прва српска парна пивара Ђорђа Вајферта 18731947, Гоgишъак іраяa Беоїpaga LIX (Београд):81-128, доступно на: http:/www.mgb.org.rs/images/stories/MGB/pdf/GodisnjakLIX-web.pdf (10.10.2014).

Мала иичвара у Скаgарлији (1971), Београд: Завод за заштиту споменика културе града Београда

Милићевић, Ђ. М. (1902), Цртице за ранију слику српске престонице, Годишњиия Николе Чуйића ХXII (Београд): 5-59.

Новаковић, С. (1911), Пиво у Србији у XIII и XIV веку, Глас Срйске Краљевске Акаяемије 86 (Београд): 151-166.

Објава (1865), Србске новине, 4. март: 98.

Оглас (1845), Србске новине, 11. август: 256

Оглас (1846), Србске новине, 7. април: 111

Оглас (1848), Србске новине, 15. октобар: 619.

Оглас (1848), Србске новине, 3. септембар: 528.

Оглас (1851), Србске новине, 10. март: 110.

Оглас (1863), Србске новине, 8. јануар: 10.
66] АC, МНП, Пф 10, p. 1/1887.

67] Лукић 2014:83-84.

68] Перишић и Милорадовић 2006: 456-458.

69] Србске новине, 14. децембар 1873, 1110.

70] Перуничић 1970: 773.

71] Србске новине, 9. јануар 1874: 44

72] Перуничић 1970: 773.

73] Истио.

74] 1981

75] Родоначелник породице Игњат Ј. Бајлони рођен је 1811. године у Литомишлу у Чешкој и оснивач је познате београдске фирме „Игњат Бајлони и синови“. У Београд се доселио 1855. године са супругом и четири сина: Јаковом, Антоном, Венцеславом и Јованом. Убрзо је 1859. године од зета Антона Њемеца откупио гостионицу, која је касније постала позната под именом „Бајлонијева“. Заједно са синовима је 1869. купио скоро напуштену државну воденицу на Млави у Малом Црнићу, где су изградили нови парни млин и пустили га у рад 1871. године. С развојем фирме „Игњат Бајлони и синови“ настављено је и након Игњатове смрти 1875 године. Браћа Бајлони су 1883. купили Парни млин у Београду, док је Мала пивара у потпуности откупљена 1888 . године.

76] Мала йивара у Скаяарлији 1971.

77] Исто.

Оглас (1871), Срйске новине, 11. март: 138

Оглас (1871), Срйске новине, 23. јун: 380

Оглас (1871), Срйске новине, 5. август: 481.

Оглас (1871), Срйске новине, 28. август: 536.

Оглас (1871), Срйске новине, 16. септембар: 582.

Оглас (1872), Срӣске новине, 16. март: 192.

Оглас (1873), Срйске новине, 14. децембар: 1110

Оглас (1874), Срйске новине, 9. јануар: 44.

Перишић, М. и Милорадовић, Г. (пр.) (2006), Живейи у Беоїраgy : Документа Управе града Београда 1868-1878, књига IV, Београд: Историјски архив Београда.

Перуничић, Б. (1970), Уйрава вароши Беоїраgа 1820-1912, Београд: Музеј града Београда

Петковић, Ђ. (2008), Јохан Вајнхапел гради млин у Параћину 1837/8. године, Корени VI (Јагодина): 35-44.

Поповић, Ј. Д. (1935), Грађа за историју Београда 1717-1739, Сйoменик Срйске Краљевске Акаяемије LXXVIII, II, 61, 2 (Београд): 163, 168, 170, 183, 187, 192, 193, 222, 223, 245.

Поповић Л. С. (1950), Пуйовање йо новој Србији 1878-1890, Београд: СК3.

Ранковић, Ј. Д. (1941), Пре сто година Државни савет је одбио предлог да се кнежевој пивари даду привилегије, Полииика, 16. март: 24.

Продаја Краљеве пиваре (1912), Политиика, 5. јун: 2.

Stanić Vajfert, B. (2007), Vajfertovi : hronika familije Vajfert u Vršcu i Pančevu. Beograd: B. Stanić Vajfert.

Тодоровић, С. (1951), Ауйобиоїрафија Сиеве Тоgоровића, Нови Сад: Матица српска.

Шабановић, Х. (1964), Турски извори за исӣорију Беоїраgа, књига 1, свеска 1, Београд: Историјски архив.

Скраћенице:

ИАБ - Историјски архив Београда

АС - Архив Србије

ЗМП - Збирка Мите Петровића

КК - Књажеска канцеларија

ДС - Државни савет

МНП - Министарство народне привреде 


\section{Summary: NENAD LUKIĆ}

\section{HAND-OPERATED BREWERIES IN 19TH-CENTURY BELGRADE}

Apart from the period from 1717 to 1739, when first hand-operated breweries were started in Belgrade by German owners, the brewing of beer in Serbia began relatively late, in the 1830s. Most of the credit for popularizing the beverage and for the development of beer making goes to merchants and master brewers from the Habsburg Monarchy, where brewing had had a long tradition. In 1839/40 Belgrade saw the opening of its first hand-operated brewery owing to a Czech, Johan Weinhappl from Sremska Mitrovica, and although we have little information about its operations, it seems that credit for the beginnings and further development of brewing should go to its founder. The economic potential of the brewing business was soon recognized by the ruling Obrenović family. In 1840 Princess Ljubica Obrenović had a new and larger brewery built, the so-called Prince's Brewery. Prince Michael Obrenović appointed a well-known master brewer from Zemun, Konstantin Hadija the Younger, as its head. After the downfall of the Obrenović dynasty, the brewery was leased to different brewers, the last of whom, from 1865 to 1873, Ignjat Vajfert (Weifert), left an indelible mark in the history of brewing in Serbia. He also owned the brewery at Pančevo, and in 1873, with his son Djordje, started the first steam-powered brewery in Belgrade. The Prince's Brewery, leased out to different organizations and firms after it ceased operating in 1873, was eventually pulled down in 1935. During the 1840s two other breweries operated in Belgrade: Milutinović Brewery, of which no closer information has survived, and Todorović-Kumanudi Brewery, which ceased operating as early as the 1850s. Filip Djordjević was yet another immigrant from the Habsburg Monarchy who left an indelible mark in the history of brewing in Belgrade. In 1850 he had a brewery built on a lot between present-day Skadarska and Cetinjska streets. It was popularly known as Filip's or Small Brewery. The brewery subsequently changed several hands, but its best known owner was certainly the Bajloni family. The Bajlonis owned it from 1888 to 1945, when it was nationalized. It continued operating under the name of Pivara Beograd (Belgrade Brewery) until 1963, when it was integrated into the newly-started Beogradska Industrija Piva or BIP (Belgrade Brewing Industry) as its Skadarlija brewing section. The Skadarlija section has been disused as a brewery since it was sold by BIP in 2005. Filip's Brewery ceased being operated by hand in 1884, but it had a tradition and history at the time of industrial beer production, whereas all other hand-operated breweries were pulled down, leaving no material trace behind.

\section{ILLUSTRATIONS}

Fig. 1 Beer making by hand (BIP Archive)

Fig. 2 Prince's Brewery, early 20th century (Belgrade City Museum)

Fig. 3 Prince's Brewery, 1920s

(V. Golubović, Mehane i kafane Starog Beograda)

Fig. 4 Small Brewery, ca 1900 (Historical Archives of Belgrade)

Fig. 5 Small Brewery, 1920s (BIP Archive) 